\title{
In vivo experiments on the safety evaluation of GM components of feeds and foods
}

\author{
Z. Zduńczyk \\ Institute of Animal Reproduction and Food Research, \\ Polish Academy of Sciences \\ Tuwima 10, 10-747 Olsztyn, Poland
}

\begin{abstract}
During the last five years, the global area of transgenic crop (GM-genetically modified) cultivation increased 25 -fold. About $98 \%$ of GM crops are grown in the USA, Argentina and Canada from where they are sent to many importers of soyabean and maize. The results of feeding experiments indicate that soyabean meal obtained from herbicide-tolerant lines and insect-resistant maize are substantially and nutritionally equivalent to their conventional lines. A higher content of insecticidal $\alpha$-amylase inhibitors (as well as lectins and alkaloids) may increase plants' resistance to insect attack, as well as the decrease nutritional value of seeds. Evaluation of the concordance of the chemical composition of transgenic and conventional crops (i.e., verification of substantial equivalence) is not sufticient for proving the safety of transgenic food. Sub-chronic in vivo experiments as well as comparison of nutritional equivalence of transgenic and conventional crops are advisable. Such actions are justificd not only by the possibility of undesirable transgenic effects, but also by the consumer's right to explicit information on food safety. Without evaluation of nutritional equivalence, information on GM-food safety is much more deficient than existing knowledge on the quality of feeds used in animal nutrition.
\end{abstract}

KEY WORDS: GM crop, safety issues, food security, in vivo evaluation

\section{INTRODUCTION}

The persisting deficiency of high-protein compounds in animal feeding explains the high position of imported soyabean in the Polish feed balance. Therefore, also in Poland-where cultivation of genetically modified plants is still not allowedGM crops are used in large amounts in animal feeding or as food product components. This is not a well-known fact and does not arouse as much interest as the 
transgenic products obtained by national biotechnological research teams. There are many premises indicating that introducing domestic or imported transgenic plants into field cultivation may evoke emotions similar to those observed in other European countries, especially in the United Kingdom. These emotions are directed mainly against the use of genetically modified organisms (GMO) in food production. Some consumers quote a well-known saying, "You are what you eat". This is an excellent motto for an article in Nature concerning the adaptation of Darwin's finches to local conditions (Ryan, 2001); but when used for GMO - it only worsens anxiety. Reluctant acceptance of transgenic products is, to a great extent, similar to the first reactions to smallpox vaccine, anesthetics, telephones, and artificial insemination (Phipps and Beever, 2000). The unexpected but still observed apprehension of the scientific community has taken form in the creation of the Union of Concerned Scientists. In December 1999, with reference to aroused emotions as well as to the chasm between GMO followers and opponents, Science pronounced "GM Foods Under Attack" as the Controversy of the Year. So far, basic questions as to possible consequences of using GMOs in animal feeding and food production have not been answered comprehensively enough.

\section{GENETIC ENGINEERING: A NEW METHOD OF PLANT BREEDING}

The use of molecular biology techniques in plant science was began in the early eighties of the last century. Earlier, since the thirties, sclection and cross breeding were the most important methods of plant breeding (Table 1). Unlike the previous methods of plant breeding, molecular biology enriches the plant genotype from any source. Plant modification using recombinant DNA technology is the insertion of a known sequence of foreign DNA into the host genome. It is thus quite distinct from mutation breeding, because it is based on initial non-random DNA change and can cross species boundaries. The new genetic information is assembled as one or more gene "cassette" consisting of promoter, coding and terminator regions (Käppeli and Auberson, 1998). Because it is impossible to screen for certain traits in individual transformants (e.g., resistance to viral diseases), genetic information for selective marker genes conferring antibiotic resistance or herbicide tolerance is co-introduced along with the primary target traits.

While evaluating the dangers of transgenic products, one should remember that conventional methods (not exempt from error) were also used to change the genotype of cultivated plants. Long-standing selection led to elimination of erucic acid and lowering of the glucosinolate content in rape. The tannin content in new white field bean cultivars and alkaloid content in lupin seeds were substantially lowered in the same manner. In all of the above-mentioned cases, the content of a component typical of a particular species was eliminated or reduced. Genetic engineering 
TABLE 1

Genetic variation and selection criteria used in traditional brecding and genetic engineering of crops (Käppeli and Auberson, 1998)

\begin{tabular}{llll}
$\begin{array}{l}\text { Method of plant } \\
\text { breeding }\end{array}$ & $\begin{array}{c}\text { Origin } \\
\text { of traits }\end{array}$ & Processes for genomic variation & $\begin{array}{l}\text { Selection criteria } \\
\text { for desirable } \\
\text { agronomic features }\end{array}$ \\
\hline Selection & Plant & $\begin{array}{l}\text { Background processes include DNA } \\
\text { rearrangement, transposition, mutation } \\
\text { and recombination, which are all } \\
\text { non-deterministic variation processes } \\
\text { of evolutionary significance. }\end{array}$ & $\begin{array}{l}\text { Sensory } \\
\text { assessment } \\
\text { in landrace }\end{array}$ \\
$\begin{array}{llll}\text { Cross brecding } \\
\text { (direct) }\end{array}$ & $\begin{array}{l}\text { Gene pools } \\
\text { of parents }\end{array}$ & $\begin{array}{l}\text { Scxual mating and background } \\
\text { processes. }\end{array}$ & $\begin{array}{l}\text { Sensory assessment } \\
\text { in progeny }\end{array}$ \\
$\begin{array}{l}\text { In vitro cell } \\
\text { culture } \\
\text { (random) }\end{array}$ & $\begin{array}{l}\text { Plant } \\
\text { genotype }\end{array}$ & $\begin{array}{l}\text { Induces mutagenesis (increases the } \\
\text { frequency of background processes); } \\
\text { somaclonal variation }\end{array}$ & $\begin{array}{l}\text { Sensory assessment } \\
\text { in regenerated } \\
\text { clones }\end{array}$ \\
$\begin{array}{l}\text { Genetic } \\
\text { cnginecring } \\
\text { (direct) }\end{array}$ & Any source & $\begin{array}{l}\text { Gene insertion (e.g. pleiotropy, } \\
\text { position effect and insertional } \\
\text { mutagenesis); somaclonal variation: } \\
\text { background processes. }\end{array}$ & $\begin{array}{l}\text { Sensory, molecular, } \\
\text { or biochemical } \\
\text { analyses in } \\
\text { regenerated plant }\end{array}$ \\
\hline
\end{tabular}

allows not only obtaining the desired effect in a much shorter time, but also enables crossing boundaries characteristic of a given species, for instance susceptibility to thermal stress, viral diseases, herbicide activity.

The first information that a transgenic plant had been obtained come in 1986 and concerned tobacco resistant to mosaic virus (Abell et al., 1986). In the next decade, genetic engineering was used to obtain and investigate the cultivation conditions for new plants with modified genotypes. In 1996, the global area of transgenic crop cultivation was 1.7 million ha; during the next five-year period it increased 25-fold to 44.2 million ha (James, 2001; Table 2). In 2000, herbicide tolerance, introduced into soyabean, maize and cotton, distinguished $74 \%$ of the 44.2 million ha of CM crops; 8.3 million ha $(19 \%)$ were planted with insect-resistant crops, and the stocked genes for herbicide tolerance and insect resistance introduced into both cotton and maize occupied $7 \%$ of the global transgenic crop cultivation area. In 2000 , four countries grew $99 \%$ of the global amount of transgenic crops: USA (68\%), Canada (7\%), Argentina (23\%) and China (1\%). The remaining $1 \%$ was grown in 9 other countries. The number of countries where GMOs are used in animal feeding and food production is still growing as the result of export of soyabean and maize by the USA. 
TABLE 2

The global area of transgenic crops in 2000 (James, 2001)

\begin{tabular}{llcrr}
\hline \multirow{2}{*}{ Plant } & Trait of transgenese & Symbol & \multicolumn{2}{c}{ Area } \\
\cline { 4 - 5 } & & & million ha & $\%$ \\
\hline Soyabean & Herbicide tolerant & tHT & 25.8 & 58.4 \\
Canola & Herbicide tolerant & tHT & 2.8 & 6.3 \\
Maize & Herbicide tolerant & tHT & 2.1 & 4.8 \\
Maize & Insect resistant & $\mathrm{Bt}$ & 6.8 & 15.4 \\
Maize & Herbicide tolerant/insect & & & 3.2 \\
& resistant & tHT/Bt & 1.4 & 4.8 \\
Cotton & Herbicide tolerant & tHT & 2.1 & 3.8 \\
Cotton & Herbicide tolerant/insect & & & 1.7 \\
Cotton & resistant & tHT/Bt & 1.5 & 3.4 \\
Total & Insect resistant & $\mathrm{Bt}$ & & \\
\hline
\end{tabular}

\section{NUTRITIONAL IMPLICATIONS OF TRANSGENIC HERBICIDE-TOLERANT PLANTS}

Improving tolerance to herbicides is the main genetic modification being made to plants. Table 3 summarizes the types of transgenic herbicide-resistant crops approved for cultivation in the European Union, the United States, Canada and/or Japan. Glyphosate-tolerant soyabeans (GTS) have been engineered for selectivity to foliar application of the herbicide glyphosate. Glyphosate is the active ingredient of the broad-spectrum of nonselective herbicide Roundup ${ }^{\circledR}$. Padgette et al. (1995) introduced a single gene that confers a high level of glyphosate tolerance to a commercial cultivar of soyabeans. This gene encodes a glyphosate-tolerant 5-enolpyruvylshikimate-3-phosphate synthetase from Agrobacterium sp. strain CP4 (CP4 EPSPS). CP4 EPSPS is present in plants, bacteria and fungi, but not in ani-

TABLE 3

Transgenic herbicide-resistant crops approved in EU, USA, Canada and/or Japan (Kuiper et al., 2000)

\begin{tabular}{lll}
\hline Herbicide & \multicolumn{1}{c}{ Target } & \multicolumn{1}{c}{ Crop } \\
\hline Bromoxynil & Photosystem II & Cotton, oilseed rape, tobacco \\
Sulfonylurea & Acetolactate synthase & Cotton, flax \\
Glufosinate & Glutamine synthase & Maize, oilseed rape, rice, soya, sugar beet \\
Glyphosate & 5-enolpyruvyl-shikimate-3 & Beet, cotton, maize, oilseed rape, soya \\
& -phosphate synthase & \\
\hline
\end{tabular}


mals, as a component of the shikimate pathway of aromatic amino acid biosynthesis. Animals do not make their own aromatic amino acids but rather receive them from plant-, microbial- or animal-derived foods.

Among all of the soyabean modifications mentioned in Table 3, increasing resistance to the herbicides Glufosinate and Glyphosate is the most frequent. Therefore, it is important to summarize the most important information on the use of herbicide-resistant soyabean. Two GTS lines (denoted 40-3-2 and 61-67-1) were obtained by particle gun bombardment of the conventional cultivar of soyabean. Products obtained from conventional and GTS lines were extensively studied with respect to different criteria. Table 4 summarizes the main results of these studies. Padgette et al. (1996) analyzed the chemical composition of seeds, batches of defatted toasted meal, defatted nontoasted meal, protein isolate, and protein concentrate. The analytical results concerning macronutrients (protein, fibre, carbohydrates, ash) and antinutrients (trypsin inhibitors, lectins, isoflavones, oligosaccharides and phytates) demonstrated that the GTS lines are equivalent to the parental, conventional soyabean cultivar.

The results of a feeding study by Hammon et al. (1996) were also similar when animals were fed diets with soyabean meal from parental and GTS lines. In an experiment carried out on rats, more distinct differences were noted between groups receiving diets containing unprocessed ground meal or processed soyabean meal, than between groups receiving diets with soyabean meal from the GTS and parental lines. There were no gross pathological findings observed at necroscopy that were considered related to genetic modification. However, the liver of several animals fed GTS and parental-line ground soyabeans appeared darker brown at necroscopy; the liver of the rats on the control diet also appeared darker. Because rats fed processed GTS and parental-line soyabean meal did not exhibit a similar incidence of darker brown liver at necroscopy, this finding may have been related to feeding rats with ground soyabeans at a high dietary level. Because this finding occurred both in rats fed ground GTS and in rats fed ground parental-line soyabeans, it was not considered to be related to genetic modification. In another study, body weight gain, feed consumption, gain:feed ratio, viability, breast and fat pad weight during the 42-day study period in chickens fed diets with about $30 \%$ of GTS and or parental line processed soyabean meal were similar. The results of a study on dairy cows were also similar when animals were fed diets with soyabean meal from parental and GTS lines. Dry matter and net energy intake were not affected by the source of soyabean used in the total mixed diets, and apparent dry matter digestibility was similar for the diets. Similarly, indices of nitrogen balance were not affected by diet. Milk production (corrected to $3.5 \%$ of fat) was even higher for diets containing $10 \%$ soyabean meal from GTS lines. In all studies, the measured variables were similar for animals fed both GTS lines and the parental line, indicating that the feeding value of the two GTS lines is comparable to that of the parental one. 
TABLE 4

Evaluation of feeding value of toasted soyabean meal from the conventional and two glyphosatetolerant lines (according to Padgette et al., 1996'; Hammond et al., 1996 and Harrison et al., 1996 ${ }^{3}$ )

\begin{tabular}{|c|c|c|c|}
\hline $\begin{array}{l}\text { Type of } \\
\text { study }\end{array}$ & The range of study & Results & Conclusion \\
\hline $\begin{array}{l}\text { Chemical } \\
\text { analysis }^{1}\end{array}$ & $\begin{array}{l}\text { The content of macronutrients } \\
\text { (protein, fibre, carbohydrates, } \\
\text { ash) and antinutrients (trypsin } \\
\text { inhibitors, lectins, isoflavones, } \\
\text { oligosaccharides and phytates) }\end{array}$ & $\begin{array}{l}\text { No significant differences in } \\
\text { the level of analysed } \\
\text { ingredients were found }\end{array}$ & $\begin{array}{l}\text { The GTS lines are } \\
\text { equivalent to the } \\
\text { parental, } \\
\text { conventional } \\
\text { soyabean cultivar }\end{array}$ \\
\hline \multirow[t]{4}{*}{$\begin{array}{l}\text { Feeding } \\
\text { study }\end{array}$} & $\begin{array}{l}\text { Feeding of rats aged } 8 \text { to } 12 \\
\text { weeks (soyabean meal } \\
24.8 \% \text { of diets) }\end{array}$ & $\begin{array}{l}\text { There were no differences in } \\
\text { feed intake and body weight } \\
\text { between rats fed dicts with } \\
\text { meal of parental line and GTS }\end{array}$ & \multirow{4}{*}{$\begin{array}{l}\text { In all studics, } \\
\text { measured variables } \\
\text { were similar for } \\
\text { animals fed both } \\
\text { GTS lines and the } \\
\text { parental line, } \\
\text { indicating that the } \\
\text { feeding value of the } \\
\text { two GTS lines is } \\
\text { comparable to that } \\
\text { of the parental line }\end{array}$} \\
\hline & $\begin{array}{l}\text { Poultry feeding - a } 6 \text {-week } \\
\text { study (soybean meal about } \\
33 \% \text { and } 27 \% \text { of starter and } \\
\text { growing diet, respectively) }\end{array}$ & $\begin{array}{l}\text { There were no difference } \\
\text { among groups for feed } \\
\text { intake, body weight and } \\
\text { indices of slaughter quality }\end{array}$ & \\
\hline & $\begin{array}{l}\text { Catfish feeding - a } 10 \text {-week } \\
\text { study (soyabean about } 40 \% \\
\text { of dicts) }\end{array}$ & $\begin{array}{l}\text { The proportional weight gains } \\
\text { and body composition of fish } \\
\text { fed the GTS and parental lines } \\
\text { were similar }\end{array}$ & \\
\hline & $\begin{array}{l}\text { Dairy cattle feeding from } 93 \\
\text { to } 196 \mathrm{~d} \text { of lactation } \\
\text { (soyabean } 10 \% \text { of daily diets) }\end{array}$ & $\begin{array}{l}\text { Milk production and } \\
\text { composition were not affected } \\
\text { by the three soyabean sources }\end{array}$ & \\
\hline $\begin{array}{l}\text { In vitro } \\
\text { digestion }^{3}\end{array}$ & $\begin{array}{l}\text { 5-enolpyruvylshikimate-3- } \\
\text { phosphate synthetase protein } \\
\text { extract (CP4 PSPS) in vitro } \\
\text { digestibility }\end{array}$ & $\begin{array}{l}\text { CP4 PSPS were readily } \\
\text { degraded in simulated gastric } \\
\text { and intestinal fluid }\end{array}$ & $\begin{array}{l}\text { CP4 PSPS will be } \\
\text { degraded in the } \\
\text { mammalian } \\
\text { digestive tract upon } \\
\text { ingestion as a } \\
\text { component of food } \\
\text { or feed }\end{array}$ \\
\hline $\begin{array}{l}\text { Acute } \\
\text { oral } \\
\text { toxicity }\end{array}$ & $\begin{array}{l}\text { Acute oral administration of } \\
\text { CP4 PSPS for } 100 \text { mice }\end{array}$ & $\begin{array}{l}\text { There were no deleterious } \\
\text { effects due to the acute } \\
\text { administration of CP4 PSPS } \\
\text { to mice by gavage at a high } \\
\text { dosage of } 573 \mathrm{mg} / \mathrm{kg} \text { body } \\
\text { weight, which exceeds } \\
1000 \text {-fold the anticipated } \\
\text { consumption level of food } \\
\text { products potentially containing } \\
\text { CP4 PSPS protein }\end{array}$ & $\begin{array}{l}\text { Obtained results } \\
\text { confirm the safety } \\
\text { of the CP4 PSPS } \\
\text { protein }\end{array}$ \\
\hline
\end{tabular}


Hammon et al. (1996) confirmed that in all studies, measured variables were similar for animals fed both GTS lines and the parental line, indicating that the feeding value of the two GTS lines is comparable to that of the parental line. The abovementioned conclusion is appropriate, however, the described studies do not cover all important applications of soyabean meal in animal feeding. There were no studies carried out on pigs, and the model of the study conducted on rats (aged 8 , and not 3-4 weeks) may arouse some reservation. Nevertheless, there are sufficient grounds for stating that the nutritional value of glyphosate-tolerant soyabean is equivalent to the parental, conventional soyabean cultivar.

Table 4 also summarizes the main results of studies concerning the biological properties of protein extracts from GTS seeds containing CP4 PSPS. CP4 PSPS were readily degraded in simulated gastric and intestinal fluid. There were no deleterious effects resulting from acute administration of CP4 PSPS to mice by gavage at a high dosage of $573 \mathrm{mg} / \mathrm{kg}$ body weight, which exceeds 1000 -fold the anticipated consumption level of food products potentially containing CP4 PSPS protein. Harrison et al. (1996) confirmed that these data, in combination with seed composition analysis and animal feeding studies, support the conclusion that glyphosate-tolerant soyabean is as safe and nutritious as the traditional soyabean currently being marketed.

The following factors are named most often as potential risks of transgenic herbicide-resistant crops: 1 . greater reliance on herbicides for weed control, 2 . increase in herbicide use, 3 . more contamination of the water, soil and air and shift in exposure patterns, 4 . development of resistance in weed species by introgression of the transgenes, 5. shifts in populations of weeds towards tolerant species, 6 . increase in volunteer problems in agricultural rotation systems, and 7. negative effect of herbicides on non-target species (Kuiper et al., 2000). As much as they are interesting, they go beyond the scope of this paper and will not be explicitly described herein.

\section{NUTRITIONAL IMPLICATIONS OF INSECT-RESISTANT PLANTS}

The first generation of insecticidal plants was introduced onto the market in 1996. This plant was denoted "Bt", because the bacterium, Bacillus thuringiensis, which produces $\delta$-endotoxin, was used as the source of the new gene (Jouanin et al., 1998). $\delta$-endotoxins are widely applied in the protection of plants against insects, especially Lepidoptera and Cleoptera. Bacillus thuringiensis was first used as a bioinsecticide and the main advantage of such formulations is that they are harmless to humans, mammals and the non-target fauna. The $\delta$-endotoxins are solubilized in the insect midgut and are activated by gut proteases that cleave the protein into a smaller polypeptide, the toxin. This toxin binds to the surface of 
epithelial cells in the midgut, inducing lesions that destroy the cells and lead to the death of the insect (Knowles and Dow, 1993).

The $\delta$-endotoxins are encoded by bacterial or synthetic gene cry (crystalline proteins) introduced into crop plants (maize, cotton). The first publications reported a very low level of expression of the bacterial cry genes, generally less than $0.001 \%$ of leaf soluble proteins. In plants expressing synthetic cry genes the level of expression of protein is higher; from 0.02 to $1 \%$ of leaf soluble proteins (Jouanin et al., 1998). Feeding investigations conducted so far do not provide grounds for stating that expression of the cry gene has a deleterious effect on the nutritional value of maize. This refers to maize seeds used in monogastric animal nutrition as well as to green fodder used in ruminant feeding. The data collected in Table 5

TABLE 5

Evaluation of feeding value of insect-resistant "Bt" maize

\begin{tabular}{|c|c|c|c|}
\hline $\begin{array}{l}\text { Type of } \\
\text { study }\end{array}$ & The range of study & Results & Authors \\
\hline $\begin{array}{l}\text { Broiler } \\
\text { feeding }\end{array}$ & $\begin{array}{l}\text { A } 38 \text {-day feeding study } \\
\text { with } 61.4 \text { and } 67.4 \% \text { of } \\
\text { transgenic or } 58.6 \text { and } \\
64.5 \% \text { of conventional } \\
\text { maize in starter and } \\
\text { growing diet, respectively }\end{array}$ & $\begin{array}{l}\text { There were no significant } \\
\text { differences in the chemical } \\
\text { composition of maize and } \\
\text { feeding results }\end{array}$ & $\begin{array}{l}\text { Brake and } \\
\text { Vlachos, } 1998\end{array}$ \\
\hline $\begin{array}{l}\text { Broiler } \\
\text { feeding }\end{array}$ & $\begin{array}{l}\text { A } 35 \text {-day feeding study } \\
\text { with } 50 \% \text { of transgenic or } \\
\text { conventional maize in } \\
\text { concentrate mixture }\end{array}$ & $\begin{array}{l}\text { There were no significant } \\
\text { differences in the diet } \\
\text { intake, body weight gain } \\
\text { and protein digestibility between } \\
\text { experimental groups }\end{array}$ & $\begin{array}{l}\text { Halle et al., } \\
1998\end{array}$ \\
\hline $\begin{array}{l}\text { Cows } \\
\text { feeding }\end{array}$ & $\begin{array}{l}\text { A } 3 \text {-week feeding study. } \\
\text { Diets with } 40 \% \text { of silage } \\
\text { and } 28 \% \text { maize grain from } \\
\text { the transgenic and } \\
\text { conventional line of maize }\end{array}$ & $\begin{array}{l}\text { There were no significant } \\
\text { differences between the } \mathrm{Bt} \\
\text { and non-Bt maize hybrids in } \\
\text { any lactation performance or } \\
\text { ruminal fermentation } \\
\text { parameter measured }\end{array}$ & $\begin{array}{l}\text { Folmer et al., } \\
2000\end{array}$ \\
\hline $\begin{array}{l}\text { Animal } \\
\text { products } \\
\text { analysis }\end{array}$ & $\begin{array}{l}\text { Estimation of the fate of } \\
\text { ingested recombinant plant } \\
\text { DNA in farm animals } \\
\text { (cattle and chicken) being } \\
\text { fed a diet with Bt and } \\
\text { conventional maize }\end{array}$ & $\begin{array}{l}\text { Except blood, in all cattle } \\
\text { organs (muscle, liver } \\
\text { spleen, kidney) plant DNA } \\
\text { were not found. No foreign } \\
\text { plant DNA fragments were } \\
\text { found in eggs, however, in } \\
\text { chicken tissues the short maize } \\
\text { chloroplast gene fragments } \\
\text { were amplified }\end{array}$ & $\begin{array}{l}\text { Einspanier et al., } \\
2001\end{array}$ \\
\hline
\end{tabular}


indicate that the effects on poultry and cows were similar when animals were fed transgenic lines and the parental line of maize.

Einspanier et al. (2001) estimated the fate of ingested recombinant plant DNA in the organs of cattle and chickens fed a diet with Bt and conventional maize. Plant DNA was found in all cattle organs (muscle, liver, spleen, kidney). However, the short maize chloroplast gene fragments were amplified in all chicken tissues. The investigations of Faust and Vlachos (after Phipps and Beever, 2001) and Einspanier et al. (2001) indicate that milk and eggs obtained from animals fed Bt maize do not contain plant DNA. Feeding studies done to date show that Bt maize is nutritionally equivalent to conventional maize and that it is safe for animal feeding.

From the animal feeding point of view, the idea of inducing the synthesis of antimetabolic proteins that interfere with digestive processes in insects seems dubious. Protease inhibitors, $\alpha$-amylase inhibitors, lectins and alkaloids, substances defined as antinutritional factors, the contents of which have been limited so far through conventional selection of cultivated plants varieties, are being used. Increasing their content in feeds may worsen animal nutrition. This was observed in the study by Pusztai et al. (1999), where a rat diet was supplemented with $30 \%$ transgenic or parent peas. Transgenic pea seeds contained about $3 \mathrm{~g} / \mathrm{kg}$ bean $\alpha$-amylase inhibitor. Control rats obtained diets with lactalbumin and lactalbumin supplemented with $\alpha$-amylase inhibitor, in levels equivalent to those in transgenic pea diets. Selected results of the study are presented in Table 6 . In a short 10-day experiment, a decrease in rat weight gain was not observed, whereas a significant increase in excreted faeces and decrease in dry matter digestibility were noted. In the group of rats fed the diet with $\alpha$-amylase inhibitor (synthetic or in pea seeds), a significantly higher mass of the caecum was noted. This proves that the activity

TABLE 6

Selected results of feeding rats with diets containing lactalbumin without $(O)$ or with $\alpha$-amylase inhibitor ( $\alpha$-AI) and $30 \%$ of sceds of parent (P) and transgenic (TR) pea (according to Pusztai et al., 1999)

\begin{tabular}{lcccc}
\hline & \multicolumn{2}{c}{ Lactalbumin } & \multicolumn{2}{c}{ Pea } \\
\cline { 2 - 5 } & 0 & $\alpha-\mathrm{Al}$ & $\mathrm{P}$ & $\mathrm{TR}$ \\
\hline Initial weight, g & 83.5 & 84.3 & 83.5 & 83.0 \\
Food intake, g/10 days & 128 & 128 & 128 & 128 \\
Weight gain, g/10 days & 69.6 & 72.2 & 76.5 & 72.4 \\
Faeces, g/10 days & $7.9^{\mathrm{a}}$ & $9.5^{\mathrm{a}}$ & $15.0^{\mathrm{b}}$ & $24.1^{\mathrm{c}}$ \\
Dry matter digestibility, $\%$ & $95.0^{\mathrm{c}}$ & $91.3^{\mathrm{bc}}$ & $87.9^{\mathrm{b}}$ & $81.7^{\mathrm{a}}$ \\
N digestibility, $\%$ & $91.1^{\mathrm{b}}$ & $88.3^{\mathrm{b}}$ & $81.6^{\mathrm{a}}$ & $79.8^{\mathrm{a}}$ \\
N balance, mg/10 days & $2270^{\mathrm{b}}$ & $2282^{\mathrm{b}}$ & $2101^{\mathrm{ab}}$ & $2028^{\mathrm{a}}$ \\
Caecum, mg/100 g dry body weight & $320^{\mathrm{a}}$ & $519^{\mathrm{b}}$ & $367^{\mathrm{a}}$ & $585^{\mathrm{b}}$ \\
\hline
\end{tabular}


of $\alpha$-amylase inhibitor in the digestive tract resulted in part of the dietary starch remaining undigested in the small intestine and reaching the caecum in greater amounts. The presented results indicate that introduction of the bean $\alpha$-amylase inhibitor gene into pea lowered the nutritional value of seeds. For this reason the title under which the results were published "Expression of the insecticidal bean $\alpha$-amylase inhibitor transgene has minimal detrimental effects on the nutritional value of peas fed to rats at $30 \%$ of the diet" was not appropriate.

In the above-mentioned study of Pusztai et al. (1999), the functional $\alpha$-amylase inhibitor content of the transgenic pea line was equivalent to $0.3 \%$ bean inhibitor/ $\mathrm{kg}$ seed. In the earlier studies of Ishimoto and Kitamura (1989) and Huesing et al. (1991), a 3-fold higher concentration of $\alpha$-amylase inhibitor in artificial diets (1\%) was toxic to the larvae of two major pests of stored legume seeds, the Bruchus beetles, Callosobruchus maculatus (cowpea weevil) and Callosobruchus chinensis (Azuki bean weevil). This suggests that efficient insecticidal levels of $\alpha$-amylase inhibitors, protease inhibitors, lectins, or alkaloids may be too high and thus may have a deleterious effect on the nutritional value of seeds. This doubt should be examined in a full cycle of animal feeding (breeding or fattening period), using animals most susceptible to particular components; experiments on rats are not sufficient for evaluation of the biological properties of alkaloids in feeds designed for pigs.

\section{NUTRITIONAL IMPLICATIONS OF OTHER TRAITS OF TRANSGENESIS}

The most important trait of transgenesis that may find an application in the nearest future is improvement of crop resistance to bacterial, fungal, and viral diseases in particular. Considerable achievements have already been obtained by Polish authors in this matter, especially in increasing crop and potato resistance to viral diseases (Hulanicka et al., 1997; Zimny et al., 2000).

Depending on the method of transgene construction, resistance may be pathogen-derived (using a pathogen) or based on nonviral genes. The most important method in the first group mentioned is coat-protein-mediated resistance (CPMR), obtained through synthesis of transgenic DNA in infected plants without disturbing the life functions of the parasite (Fitchen and Beachy, 1993). An interesting example of the second type of transformation is introduction of the animal gene, 2'-5'oligoadenylate synthetase, to a plant, inducing the synthesis of endogenous ribonuclease that degrades single-strand viral RNA (Truve et al., 1993). Both types of transformation may slightly affect the chemical composition of transformation products. It is assumed that introduction of the CPMR gene brings about synthesis of considerable amounts of transgenic DNA and RNA, and small amounts of proteins. Phenotype changes in plants can be insignificant and not affect their nutri- 
tional usefulness. Also 2'-5'oligoadenylate synthetase, commonly occurring in animals, should not affect the nutritional value of transgenic crops. It is possible that the nutritional value of components, e.g., potatoes devoid of numerous necroses caused by viral diseases, may even be increased. This assumption, however, should be verified by a feeding study.

Another promising trait of transformation is improvement of the nutritional value of crops. In animal feeding, soyabean meals processed from genetically modified high-protein soyabeans have already been used. Transgenic soyabean meal, containing over $60 \%$ crude protein, gave similar feeding results in cockerels to those of soyabean meal from conventional lines (Edwards et al., 2000). Similar modifications may increase the lysine content in soyabean protein (Parsons and Zhang, 1997) and utilization of phytate phosphorus (Denbow et al., 1998).

A feeding study aiming at evaluating the nutritional value of seeds with an improved composition should cover two elements: range of beneficial changes (e.g., increasing digestible methionine) as well as the possibility of deleterious genetic changes. The latter possibility is real due to the low precision of introducing the gene. Both using bacterial cells as microprojectiles, particle bombardment techniques, and use of polyethylene glycol lead to a random location of the introduced gene in the host genome. This may evoke undesirable changes in the chemical composition and nutritional value of transgenic crops.

Safety and economical advantages will decide about the possible practical application of other genetic modifications, previously tested on a laboratory scale, influencing among others: 1 . plant architecture and flowering, including plant height, flowering and ripening times, 2 . increased tolerance to environmental stresses including cold, water, and saline soil, 3 . the enhancement of vitamin, mineral and anticancerogenic substance contents, 4 . oil, starch and protein modification to provide supplies of raw materials for biodegradable plastics, 5 . the production of pharmaceutical substances, e.g., anticoagulant compounds, edible vaccines (Dale, 1999).

\section{ASSESSMENT OF GM-FOOD SAFETY}

According to FAO/WHO experts (1996), the necessary scope of safety evaluation of food containing genetically modified organisms, GMOs, depends on the effect of the modification process on the chemical composition and properties of products. According to that concept, most of the already-introduced genetic modifications belong to the first group of GMOs, i.e., products that were found significantly similar to already-existing conventional food. Similarity is stated on the basis of two criteria: 1. phenotype evaluation, i.e., comparison of morphology, growth, flowering, resistance to diseases and other properties with these of unmodified plants, animals and microorganisms; 2 . chemical evaluation, i.e., deter- 
mination of the most important nutritional components and antinutrients (including antinutritional or toxic ones) typical of the species being modified and the source of the extraneous gene. If the differences in the contents of the analyzed components are within the range of natural diversity (e.g., variety differences within plant or animal species), then it can be assumed that modified as well as conventional food raw material are equivalents. Although verifying this assumption is not obligatory, such a raw material should be a nutritional equivalent, i.e., it should assure similar effects as conventional raw materials in animal feeding. The previously mentioned studies using glyphosate-tolerant soyabeans and $\mathrm{Bt}$ insect-resistant maize, which concluded that these GM products are as safe and nutritious as traditional soyabean and maize currently being marketed, were conducted according to the above-mentioned criteria.

The second group of GMO-food noted in the FAO/WHO report (1996), consists of products that were found to be significantly similar to already-existing conventional food, except for precisely defined differences. From the previous examples of genetic modification of feed raw materials, plants with a genetically increased content of protease inhibitors, $\alpha$-amylase inhibitors, lectins and alkaloids can be included in this group of products. In the case of this group of GMOs, evaluation of compositional equivalence comprises desirable change of the content of a selected component. In respect to this GMO group, special attention is also being paid to potential allergenic properties that may arise as a result of the synthesis of a new protein. The third group of food products obtained by genetic modification comprises products that do not show significant similarity to alreadyexisting conventional food. Only in this case, i.e., in relation to GMO, is it necessary to conduct full feeding and toxicological investigations on animals in order to prove their safety.

The above-mentioned safety rules for using GMOs have numerous opponents. In the opinion of some consumers' groups, genetically modified products already introduced into the market (tomatoes and strawberries with prolonged shelf-lives, cucumbers enriched with "sweet" proteins, insect-resistant apples, cabbage and pumpkin as well as viral disease- resistant potatoes, wheat and rape) differ so much from conventional products that they deserve to be called „Frankenfood” (Dale, 1999). Opponents' opinions were the most explicitly expressed by Millstone et al. (1999), who said that showing that a genctically modified food is chemically similar to its natural counterpart is not adequate evidence that it is safe for human consumption. Millstone et al. (1999) suggested that substantial equivalence, which was first introduced in 1993 by the Organization for Economic Cooperation and Development (OECD, 1993) and was endorsed in 1996 by the FAO and WHO (FAO/WHO, 1996), is a pseudo-scientific concept because it is a commercial and political judgment masquerading as if it were scientific. Consequently, for Millstone et al. (1999) one obvious solution at the time would have been for legislators 
to have treated GM foods in the same way as novel chemical compounds, such as pharmaceuticals, pesticides and food additives, and to have required companies to conduct a range of toxicological tests, the evidence from which could be used to set 'acceptable daily intake' (ADIs). Discussion evoked by the above concept had a profound share in the verdict of the Science Editors in December 1999 - controversy of the Year: GM Foods Under Attack.

It is obvious that with reference to food, apart from ecological issues (which are not discussed), it is necessary to consider all aspects of safe use of GMOs, including potential allergenic properties, possible transfer of DNA to animal products and human organisms, transfer from GM plant material to bacteria residing in the gastrointestinal tract and adverse changes in chemical composition and nutritional value. It is known that $90 \%$ of allergies come from common allergenic food, such as milk, eggs, fish, tree nuts and legumes. The finding of allergenic properties of products in which the content of methionine was increased through introduction of a gene from Brazil nuts, proves that similar results may be observed in each modification of protein composition. Many consumers are afraid of the transfer of transgenic DNA to the human organisms. Some works suggest that intact DNA may survive, cross the gut epithelium, enter the blood stream and interact with mammalian cells. Schubbert et al. (1997), calculated that $2-4 \%$ of orally administered DNA was detected in the gastrointestinal tract and $0.1-0.01 \%$ was retrieved from blood. Recent work on the fate of DNA in vivo has added to the understanding of the rate at which consumed DNA is destroyed by natural processes (Mercer et al., 1999). Probably, DNA may remain available for transformation in the oral cavity but is rapidly inactivated further down the gastrointestinal tract. A limited number of studies have attempted to investigate DNA transfer from GM plant material to microorganisms. These studies tend to confirm the view that such an event would be extremely rare (Beever and Kemp, 2000; Gasson, 2000).

An increase in the content of substances that disturb the digestion and metabolism of food components as well as those lowering the nutritional value of products may be an undesirable effect of transgenesis. The techniques of introducing the extraneous gene do not make it possible to foresee where the recipient DNA chain will be changed. Introduced DNA may destroy sequences of a gene encoding an important functional trait or may reveal a negative trait that had been dormant so far. Taking into consideration all these circumstances, a compromise should be found between the opinion of Millstone et al. (1999), and solutions currently accepted by $\mathrm{FAO} / \mathrm{WHO}$ experts. In the newest $\mathrm{FAO} / \mathrm{WHO}$ report (2000), the rule of substantial equivalence as the basis for safety assessment of genetically modified foods is upheld. It is assumed that animal testing may be deemed necessary if the characterization of the food indicates that the available data are insufficient for a thorough safety assessment. This would be particularly relevant in the case if the food was expected to make a significant dietary contribution, if there is no history 
of consumption of the novel gene product or if the modification affects several metabolic pathways. More extended studies are assumed in the case where the genetically modified food differs from the traditional counterpart by the presence of one or a few new genes and their products. In such cases, it is generally considered that a sub-chronic study of 90 -day duration is the minimum requirement to demonstrate the safety of repeated consumption of a food in the diet. It is also advised that conventional toxicity testing of food additives should be used with reference to isolated products of extraneous gene expression. Such a solution, however, does not consider the previously presented misgivings that the rule of substantial equivalence, preferred by GMO producers, is insufficient for evaluation of safe use of transgenic food (Millstone et al., 1999). Therefore, the best solution would be acceptance of the rule that each GM-food must be evaluated according to the criterion of nutritional equivalence to their conventional products. Application of a 90-day sub-chronic study for this evaluation may only slightly extend the time and increase the cost of introducing such new food products. It will make it possible to decide about the necessity of conducting toxicological tests on the basis of the results of biological studies, and not on the basis of disputable evaluation of genetic changes in food raw material. Such a solution is strongly supported both by opponents of transgenic food as well as by consumers' rights groups demanding more explicit information on food safety. Without evaluation of nutritional equivalence, information on GM-food safety is much more deficient than knowledge about the quality of feeds used in animal feeding.

\section{REFERENCES}

Abell P.P., Nelson R.S., Barun D.E., Hoffman N., Roger S.G., Fraley R.T., Beachy R.N., 1986. Delay of disease development in transgenic plants that express the tobacco mosaic virus coat protein gene. Science 232, 738-743

Beever D.E., Kemp C.F., 2000. Safety issues associated with DNA in animal feed derived from genetically modified crops. A review of scientific and regulatory procedures. Nutr. Abstr. Rev., Ser. B 70, 175-182

Brake J., Vlachos D., 1998. Evaluation of transgenic even 176 "Bt" maize in broiler chickens. Poultry Sci. 77, 648-653

Dale P.J., 1999. Public reactions and scientific responses to transgenic crops. Curr. Opin. Biotechnol. $10,203-208$

Denbow D.M., Grabau E.A., Lacy G.H., Kornegay E.T., Russell D.R., Umbeck P.F., 1998. Soybean transformed with a fungal phytase gene improve phosphorus availability for broilers. Poultry Sci. 77, 878-881

Einspanier R., Klotz A., Kraft J., Aulrich K., Poser R., Schwägele F., Jahreis G., Flachowsky G., 2001. The fate of forage plant DNA in farm animals: a collaborative case-study investigating cattle and chicken fed recombinant plant material. Eur. Food Res. Tech. 212, 129-134

Edwards H.M., Douglas M.W., Parsons C.M., Baker D.H., 2000. Protein and energy evaluation of soybean meals processed from genetically modified high protein soybeans. Poultry Sci. 79, 525-527 
FAO/WHO, 1996. Biotechnology and Food Safety. Report of a Joint FAO/WHO Consultation. Rome FAO/WHO, 2000. Safety Aspects of Genetically Modified Foods of Plant Origin. Report of a Joint FAO/WHO Expert Consultation of Foods Derived from Biotechnology. WHO Headquarters, Geneva

Fitchen J.H., Beachy R.N., 1993. Genetically engineered protection against viruses in transgenic plant. Ann. Rev. Microbiol. 47, 739-763

Folmer J.D., Grant R.J., Milton C.T., Beck J.F., 2000. Effect of Bt maize silage on short-term lactational performance and ruminal fermentation in dairy cows. J. Dairy Sci. 83, 1182 (Abstr. 272)

Gasson M.J., 2000. Gene transfer from genetically modified food. Curr. Opin. Biotechnol. 11, 505-508

Halle 1., Aulrich K., Flachovsky G., 1998. Einsatz von Maiskömen der Sorte Cesar und des gentechnische verndärten Bt-Hybriden in der Broilermast (in German). 5. Tagung Schweine und Geflügelernährung. Matin Luther-Universität, Halle-Wittenberg, Lutherstadt Wittenberg, pp. 265-267

Hammond B.G., Vicini J.L., Hartnell G.F., Naylor M.W., Knight Ch.D., Robinson E.H., Fuchs R.L., Padgette S.R., 1996. The feeding value of soybean fed to rats, chickens, catfish and dairy cattle is not altered by genetic incorporation of glyphosate tolerance. J. Nutr. 126, 717-727

Harrison L.A., Bayley M.R., Naylor M.W., Ream J.E., Hammond B.G., Nida D.L., Burnette B.L., Nickson T.E., Mitsky T.A., Taylor M.L., Fuchs R.L., Padgette S.R., 1996. The expressed protein in glyphosate-tolerant soybean, 5-enolyruvylshikimate-3-phosphate syntethase from Agrobacterium sp. strain CP4, is rapidely digested in vitro and is not toxic to acutely gavaged mice. J. Nutr. 126, 728-740

Huesing J.E., Shade R.E., Chrispecls M.J., Murdock L.L., 1991. $\alpha$-Amylase inhibitor, not phytohemagglutinin, explains resistance of common bean seeds to cowpea weevil. Plant Physiol. 96, 993-996

Hulanicka M.D., Zagórski-Ostoja W, Pałucha A., 1997. Non-conventional strategies to protect plants against viral infections (in Polish). Zesz. Nauk. AR Kraków 318, No. 50, 119-126

Ishimoto M., Kitamura K., 1989. Growth inhibitory effect of an $\alpha$-amylase inhibitor from kidney bean, Phaseolus vulgaris (L.) on three species of bruchids (Coleptera:Bruchidae). Appl. Entomol. Zool. 24, 281-286

James C., 2001. Global Status of Commercialized Transgenic Crops: 2000. International Service for the Acquisition of Agri-biotech Applications. Brief 21, 1-7

Jouanin L., Bonade-Bottino M., Girard C., Morrot G., Giband M., 1998. Transgenic plants for insect resistance (review). Plant Sci. 131, 1-11

Käppeli O., Auberson L., 1998. How safe is safe enough in plant genetic engineering. Trends Plant Sci. Perspect. 3, 276- 281

Knowles B.H., Dow J.A.T., 1993. The crystal $\delta$-endotoxin gene of Bacillus thuringiensis: model of action on the insect gut. Bioassays 15, 469-476

Kuiper H., Kleter G.A., Noordam M.Y., 2000. Risk of the release of transgenic herbicide-resistant plants with respect to humans, animals, and the environment. Crop Prot. 19, 773-778

Lambert B., Peferoen M., 1992. Insecticidal promise of Bacillus thuringiensis. Facts and mysteries about a successful biopesticide. Bioscience 42, 112-122

Mercer D.K., Scott K.P., Bruce-Johnson W.A., Glover L.A., Flin H.J., 1999. Fate of free DNA and transformation of the oral bacterium Steptococcus gordonii DLl by plasmid DNA in human saliva. Appl. Environ. Microbiol. 65, 6-10

Millstone E., Bruner E., Mayer S., 1999. Beyond "substantial equivalence". Nature 401, 525-526

OECD, 1993. Safety Evaluation of Foods Derived by Modern Biotechnology. Concept and Principles. OECD, Paris

Padgette S.R., Kolacz K.H., Delannay X., Re D.B., LaVallee B.J., Tinius C.N., Rhodes W.K., Otero Y.I., Barry G.F., Eicholz D.A., Peschke V.M., Nida D.L., Taylor N.B., Kishore G.M., 1995. 
Development, identification and characterization of a glyphosate-tolerant soybean line. Crop Sci. $35,1451-1461$

Padgette S.R., Taylor N.B., Nida D.L., Bailey M.R., MacDonald J., Holden L.R., Fuchs R.L., 1996. The composition of glyphosate-tolerant soybean seeds is equivalent to that of conventional soybeans. J. Nutr. 126, 702-716

Parsons C.M., Zhang Y., 1997. Digestibility of amino acids in high-lysine soybean meal. Poultry Sci. 76, Suppl. 1, 85 (Abstr. 339)

Phipps R.H., Beever D.E., 2000. New technology: Issues relating to the use of genetically modified crops. J. Anim. Feed Sci. 9, 543-561

Pusztai A., Grant G., Bardocz S., Alonso R., Chrispeets M.J., Schroeder H.E., Tabe L.M., Higgins T.J.V., 1999. Expression of the insecticidal bean $\alpha$-amylase inhibitor transgene has minimal detrimental effect on the nutritional value of peas fed to rats at $30 \%$ of the diet. J. Nutr. 129 , $1597-1603$

Ryan M.J., 2001. Food, song and speciation. Nature 409, 139-140

Schubbert R., Renz D., Schmitz B., Doerfler W., 1997. Forcign (M13) DNA ingested by mice reached peripheral leukocytes, spleen, and liver via the intestinal wall mucosa and can be linked to mouse DNA. Proc. Nat. Acad. Sci. USA 94, 961-966

Truve E., Aaspollu A., Honkanen J., Puska R., Metho M., Hassi A., Teeri T.H., Kelve M., Seppanen P., Saarma M., 1993. Transgenic potato plants expressing mammalian 2'-5'oligoadenylate synthetase and protected from potato virus $\mathrm{X}$ infection under field conditions. Biotechnology 11 , 1048-1052

Zimny J., Sowa S., Menke-Milczarek I., Czaplicki A., Sowa A., 2000. Polish transgenic cereal crops (in Polish). Biotechnologia 4, 80-87

\section{STRESZCZENIE}

\section{Doświadczenia in vivo w ocenie bezpieczeństwa stosowania genetycznie modyfikowanych skladników pasz i żywności}

W ostatnich 5 latach całkowita powierzchnia upraw roślin transgenicznych (GM) wzrosła dwudziestopięciokrotnie. Około 98\% roślin GM jest uprawianych w USA, Argentynie i Kanadzie, skąd trafiają one do importerów soi i kukurydzy. Wyniki doświadczeń żywieniowych wskazuja, że skład chemiczny i wartość pokarmowa poekstrakcyjnej śruty sojowej otrzymanej z linii odpornych na herbicydy, jak również nasion kukurydzy z linii odpornych na owady, nie różnią się składem i wartością od roślin konwencjonalnych. Zwiększona zawartość inhibitorów $\alpha$-amylazy, jak również lektyn i alkaloidów, może zwiçkszyć odpomość roślin na owady, lecz także może obniżyć wartość pokarmową nasion. Ocena zgodności składu chemicznego roślin transgenicznych i konwencjonalnych (tj. ocena równoważności składu chemicznego) nie jest wystarczająca do stwierdzenia bezpicczeństwa stosowania GM w produkcji żywności. Wskazane są subchroniczne doświadczenia in vivo i ocena równoważności pokarmowej surowców transgenicznych i konwencjonalnych. Takie postępowanie jest uzasadnione zarówno możliwością wystąpienia niezamierzonych efektów transgenezy, jak i prawem konsumentów do pełniejszej informacji o bezpieczeństwie żywności, która jest znacznie uboźsza niż wicdza o jakości pasz stosowanych w żywieniu zwierząt. 